\title{
Length-Weight Relationships for Several Copepods Dominant in the Georges Bank-Gulf of Maine Area
}

\author{
R. E. Cohen and R. G. Lough \\ National Marine Fisheries Service, Northeast Fisheries Center \\ Woods Hole, Massachusetts 02543, USA
}

\begin{abstract}
Several existing length-weight relationships for the copepods Pseudocalanus sp., Paracalanus parvus, Centropages typicus, Centropages hamatus, Oithona sp., Calanus finmarchicus, and Acartia sp., which are common in the surface waters of the Georges Bank-Gulf of Maine area, are examined and possible sources of variation among the relationships are discussed. Ideally, length and weight measurements should be carried out on fresh specimens and specific equations determined for all stages of each species at different times and locations. However, this procedure, which may be applicable to small-scale studies involving a limited number of taxonomic groups, is too time-consuming and expensive for use in general monitoring studies. In situ methods, currently being developed for recording standing crop in order to estimate productivity, will be more cost-effective for broad-scale monitoring surveys.
\end{abstract}

\section{Introduction}

The literature contains numerous length-weight (biomass) conversion relationships for marine zooplankton which may be useful in general monitoring studies where length is more easily and readily measured than weight. The Northeast Fisheries Center, National Marine Fisheries Service, Woods Hole, Massachusetts, is currently conducting ecosystem dynamic studies on the continental shelf from the Gulf of Maine to Cape Hatteras. These studies focus on the critical zooplankton-fish linkages and are based upon measures of biomass (Sherman et al., 1979; Sherman, 1980). Knowledge of the prey biomass is necessary for investigations into the relationship between larval fish feeding (gut contents) and the natural food supply (Ivlev, 1961). Bioenergetic studies of larval fish feeding and survival, such as those conducted by Laurence (1977), Radtke and Dean (1979) and Lasker (1973), require estimates of the dry weight and caloric value of the prey consumed.

In this paper, a comparison and evaluation is made of several length-weight relationships for each of the dominant species of copepods consumed by autumnspawned larval herring (Clupea harengus L.) in the Georges Bank-Gulf of Maine area. The rationale and methodology of the larval herring feeding studies are described elsewhere (Cohen and Lough, MS 1979).

\section{Materials and Methods}

The dominant food organisms of larval herring in the Georges Bank-Gulf of Maine area, based on the work of Cohen et al. (MS 1980), are the juveniles and adults of the following copepods: Pseudocalanus sp., Paracalanus parvus, Centropages typicus, Centropages hamatus, Oithona sp., and Calanus finmarchicus, and various length-weight relationships for these species have been selected from the literature for comparison and evaluation (Table 1). Some recent work on Acartia clausi (Durbin and Durbin, 1978) is also included in this study because the methods and results are clearly specified and therefore useful in evaluating earlier studies of this species.

Geographic and seasonal differences in body size and biomass exist (Bogorov, 1934; Comita et al., 1966; Conover, 1968; Siefkin and Armitage, 1969), and equations need to be selected accordingly. Added variability in the data is created by a general lack of uniformity in laboratory methods used to determine the lengths and weights. Durbin and Durbin (1978) and Robertson (1968) used fresh specimens in their investigations, whereas the other equations apply to formalinpreserved animals. Schwartz (MS 1977) combined several stages in his study of Calanus finmarchicus, causing his results to be less refined than those of other workers.

The length-weight equations used in this study have been standardized to the exponential form, $W=$ $a L^{b}$, where $W$ is the dry weight $(\mathrm{mg})$ (Corkett and McLaren, 1978; Davis, MS 1977; Durbin and Durbin, 1978; Robertson, 1968; Schwartz, MS 1977) or wet weight (mg) (Anon., MS 1976; Chislenko, 1968; Gruzov and Alekseyeva, 1970; Kamshilov, 1951; Krylov, 1968; Pertsova, 1967; Shmeleva, 1963), L is the cephalothorax length $(\mathrm{mm})$ in studies using dry weight or total 
TABLE 1. Length-weight relationships for several copepods from various literature sources. ("preceding author indicates that equations are based on total length and wet weight, whereas the others are based on cephalothorax length and dry weight: $L$ in $\mathrm{mm}$ and $W$ in $\mathrm{mg}$ ).

\begin{tabular}{|c|c|c|c|c|}
\hline Literature source & Species & Equation & Size $(\mathrm{mm})^{\mathrm{a}}$ & Region \\
\hline${ }^{*}$ Anonymous (MS 1976) & $\begin{array}{l}\text { Pseudocalanus elongatus } \\
\text { Centropages typicus } \\
\text { Calanus finmarchicus }\end{array}$ & $\begin{array}{l}W=0.0237 L^{3.745} \\
W=0.0214 L^{3.87} \\
W=0.0257 L^{3.141}\end{array}$ & $\begin{array}{l}? \\
? \\
1.3-4.0\end{array}$ & $\begin{array}{c}\text { Georges Bank } \\
\text { "I } \\
\prime i\end{array}$ \\
\hline${ }^{\star}$ Chislenko $(1968)^{\mathrm{b}}$ & $\begin{array}{l}\text { Pseudocalanidae } \\
\text { Paracalanidae } \\
\text { Calanidae } \\
\text { Centropagidae } \\
\text { Oithona sp. } \\
\text { Acartiidae }\end{array}$ & $\begin{array}{l}W=0.0181 L^{3.0694} \\
W=0.02937 L^{3.0111} \\
W=0.0309 L^{3.069} \\
W=0.0090 L^{2.969}\end{array}$ & $\begin{array}{l}? \\
? \\
? \\
?\end{array}$ & $\begin{array}{l}? \\
? \\
? \\
?\end{array}$ \\
\hline $\begin{array}{l}\text { Corkett and McLaren } \\
\qquad(1978)\end{array}$ & Pseudocalanus sp. & $W=0.0119 L^{3.64}$ & $?$ & Canadian Arctic \\
\hline Davis (MS 1977) & Pseudocalanus minutus & $W=e^{4.6097 L-8.7551} \quad\left(r^{2}=0.95\right)$ & $?$ & Georges Bank ${ }^{c}$ \\
\hline $\begin{array}{l}\text { Durbin and Durbin } \\
\text { (1978) }\end{array}$ & $\begin{array}{l}\text { Acartia clausi } \\
\text { Acartia clausi } \\
\text { Acartia clausi }\end{array}$ & $\begin{array}{ll}W=0.013185 L^{3.1858} & \left(r^{2}=0.77\right) \\
W=0.009923 L^{3.0778} & \left(r^{2}=0.98\right) \\
W=0.01237 L^{3.6276} & \left(r^{2}=0.94\right)\end{array}$ & $\begin{array}{l}\mathrm{C} 1 \\
\mathrm{C} 2-\mathrm{C} 5 \\
\mathrm{C} 6\end{array}$ & $\begin{array}{c}\text { Narragansett Bay } \\
\text { "' } \\
\text { "' }\end{array}$ \\
\hline $\begin{array}{l}\text { *Gruzov and Alekseyeva } \\
\qquad(1970)\end{array}$ & $\begin{array}{l}\text { Pseudocalanidae } \\
\text { Paracalanidae } \\
\text { Calanidae } \\
\text { Centropagidae } \\
\text { Acartiidae }\end{array}$ & $\begin{array}{l}W=0.015 L^{2.818}(\text { mean error, } \pm 17 \%) \\
W=0.028 L^{3.009}(\text { mean error, } \pm 15 \%) \\
W=0.017 L^{3.066}(\text { mean error, } \pm 20 \%)\end{array}$ & $\begin{array}{l}? \\
? \\
?\end{array}$ & $\begin{array}{c}\text { Gulf of Guinea } \\
\text { ", }\end{array}$ \\
\hline${ }^{\star}$ Kamshilov (1951) & $\begin{array}{l}\text { Calanus finmarchicus } \\
\text { Calanus hyperboreus }\end{array}$ & $W=(0.313 L-0.083)^{3}$ & $?$ & Barents Sea \\
\hline${ }^{\star}$ Krylov (1968) & $\begin{array}{l}\text { Calanus finmarchicus } \\
\text { Calanus finmarchicus } \\
\text { Centropages hamatus } \\
\text { Centropages hamatus } \\
\text { Centropages typicus } \\
\text { Paracalanus parvus } \\
\text { Paracalanus parvus } \\
\text { Paracalanus parvus } \\
\text { Pseudocalanus elongatus } \\
\text { Pseudocalanus elongatus } \\
\text { Oithona similis } \\
\text { Oithona similis } \\
\text { Oithona similis }\end{array}$ & $\begin{array}{l}W=0.0242 L^{3} \\
W=0.0292 L^{3} \\
W=0.0281 L^{3} \\
W=0.0445 L^{3} \\
W=0.0362 L^{3} \\
W=0.0426 L^{3} \\
W=0.0392 L^{3} \\
W=0.0435 L^{3} \\
W=0.0364 L^{3} \\
W=0.0336 L^{3} \\
W=0.0159 L^{3} \\
W=0.0234 L^{3} \\
W=0.0080 L^{3}\end{array}$ & $\begin{array}{l}? \\
? \\
? \\
? \\
? \\
? \\
? \\
? \\
? \\
? \\
? \\
? \\
?\end{array}$ & $\begin{array}{l}\text { Barents Sea } \\
\text { North Atlantic } \\
\text { " } \\
\text { White Sea } \\
\text { Adriatic Sea } \\
\text { North Atlantic } \\
\text { Black Sea } \\
\text { Adriatic Sea } \\
\text { White Sea } \\
\text { Black Sea } \\
\text { White Sea } \\
\text { Black Sea } \\
\text { North Atlantic }\end{array}$ \\
\hline${ }^{\star}$ Pertsova (1967) & $\begin{array}{l}\text { Centropages hamatus } \\
\text { Pseudocalanus elongatus }\end{array}$ & $\begin{array}{l}W=(0.334 L+0.0142)^{3} \\
W=(0.300 L+0.0372)^{3}\end{array}$ & $0.4-1.4$ & $\begin{array}{c}\text { White Sea } \\
\text { "I }\end{array}$ \\
\hline Robertson (1968) & $\begin{array}{l}\text { Pseudocalanidae } \\
\text { Paracalanidae } \\
\text { Centropages hamatus } \\
\text { Calanus finmarchicus } \\
\text { Acartia clausi }\end{array}$ & $\begin{array}{ll}W=0.01816 L^{2.39} & \left(r^{2}=0.65\right) \\
W=0.006458 L^{3.9} & \left(r^{2}=0.77\right) \\
W=0.01318 L^{2.86} & \left(r^{2}=0.78\right)\end{array}$ & $\begin{array}{l}\mathrm{C} 5-\mathrm{C} 6 \\
\mathrm{C} 5-\mathrm{C} 6 \\
\mathrm{C} 5-\mathrm{C} 6\end{array}$ & $\begin{array}{l}\text { North Atlantic } \\
\text { and North Sea } \\
\text { " }\end{array}$ \\
\hline Schwartz (MS 1977) & Calanus finmarchicus & $W=0.002305 \times 10^{0.6966 L}$ & $?$ & Georges Bank $^{d}$ \\
\hline *Shmeleva (1963) & $\begin{array}{l}\text { Paracalanus parvus } \\
\text { Oithona similis } \\
\text { Oithona atlanticus } \\
\text { Oithona sp. }\end{array}$ & $\begin{array}{l}W=0.034 L^{2.419} \\
W=0.016 L^{2.213} \\
W=0.013 L^{2.174}\end{array}$ & $\begin{array}{l}? \\
? \\
?\end{array}$ & $\begin{array}{l}\text { Adriatic Sea } \\
\qquad, \\
\text { Atlantic and } \\
\text { Adriatic Sea }\end{array}$ \\
\hline
\end{tabular}

\footnotetext{
a $\mathrm{C}$ refers to copepodite stage;

b Equations generated from nomographs based upon shape most closely resembling species of interest;

${ }^{c}$ Winter;

d Spring.
} 
length $(\mathrm{mm})$ in studies using wet weight, and $a$ and $b$ are constants. Appropriate lengths were substituted into all equations for each species and the mean weight plotted for each length value.

\section{Results}

Considerable variation in the length-weight relationships for the various species (Table 1) is to be expected because of differences in length and weight measurements, laboratory-processing methods, and area and season of sampling. The range of the composite length-weight curves represented in Fig. 1 and 2 tends to increase with increasing size for all species, possibly because the older animals have a wide range of length within the same stage. For example, adult females of Pseudocalanus sp. may vary from 0.67 to $1.90 \mathrm{~mm}$ (Corkett and McLaren, 1978). Pearre (1980) discusses the bases for several of the methods used to derive the equations cited.

\section{Discussion}

One approach to assessing the energy content of copepods is to determine their biomass or dry weight by some method. Ideally, unpreserved individuals of all stages of each copepod species of interest from selected field samples should be processed to determine the basic length-weight relationships in a standard form (e.g., $Y=a X^{\mathrm{b}}$ ). Biomass (energy content) can then be calculated when only the sample mean length and number of individuals are recorded (Landry, 1978; Durbin and Durbin, 1978). Pearre (1980) points out that width would be a more appropriate linear measurement than length because the latter is somewhat ambiguous in view of the different morphologies of the major copepod groups and the variety of measuring conventions used by different workers. Width seems to be a more critical dimension than length in prey selection by larval fish, but little attention has been given to this measurement in the literature.

An alternative method must be used to determine biomass from previously preserved samples. In the present study, several existing length-weight relationships for each of the common copepod species are examined. Comparisons of these equations within species are difficult because of geographic and seasonal differences in copepod body size. Some generalizations about the main factors controlling copepod length and weight (temperature and food concentration) are found in the literature. Both length and weight are positively correlated with food concentra- tion and inversely related to temperature (Deevey, 1960; Durbin and Durbin, 1978; Mullin and Brooks, 1970). Food concentration may affect length only indirectly by influencing developmental rate and therefore determining the temperatures encountered during growth (McLaren, 1963).

When considering preserved samples, the additional influence of formalin on weight and length should be noted. Most researchers agree that cephalothorax length of copepods is not significantly affected by formalin preservation, but there is some question about the effect of formalin on dry weight and other chemical constituents (Lovegrove, 1966; Fudge, 1968). Changes in dry weight (Mullin and Brooks, 1970) and carbon and nitrogen (Durbin and Durbin, 1978) stabi$\because$ e after the samples have equilibrated for several months. Corkett and McLaren (1978) suggest that the lack of a consistent relationship between preserved ar $t$ unpreserved dry weight of copepods collected at $\because$ same time is due to the seasonally changing fat cuntent (soluble in formalin). When fat content is low, there should be less discrepancy between the weights than when it is high. Landry (1978) states that, when food concentration is high, Acartia clausi copepodites accumulate excess carbon in a formalin-soluble form (probably lipid) which is not detected in the weight of animals preserved in formalin. He further suggests that this accumulated carbon is a good measure of immediate condition. Durbin and Durbin (1978) recommend calculating a condition factor for copepods, as is commonly done in fishery biology, in order to obtain a better estimate of energy content.

On the basis of these considerations and the available information, equations should be selected from Table 1 according to the requirements of the investigation, considering season, geographic area, and type of length and weight measurements taken.

Time and effort could be saved during future surveys if real-time methods of recording zooplankton biomass could be perfected. One such procedure, the "weight-dependent" method of estimating standing crop and secondary production (Mullin and Huntley, vers. comm.) could be applied to preserved samples as they are sorted by image analysis techniques or to data intained from in situ electronic zooplankton counters ich as the one described by Herman and Dauphinee (1980). Beers (1976) reviewed the literature on the selection and determination of zooplankton biomass measures and made recommendations which are basically in agreement with those proposed here. He suggested that more accurate, expensive, and timeconsuming techniques of estimating biomass should 


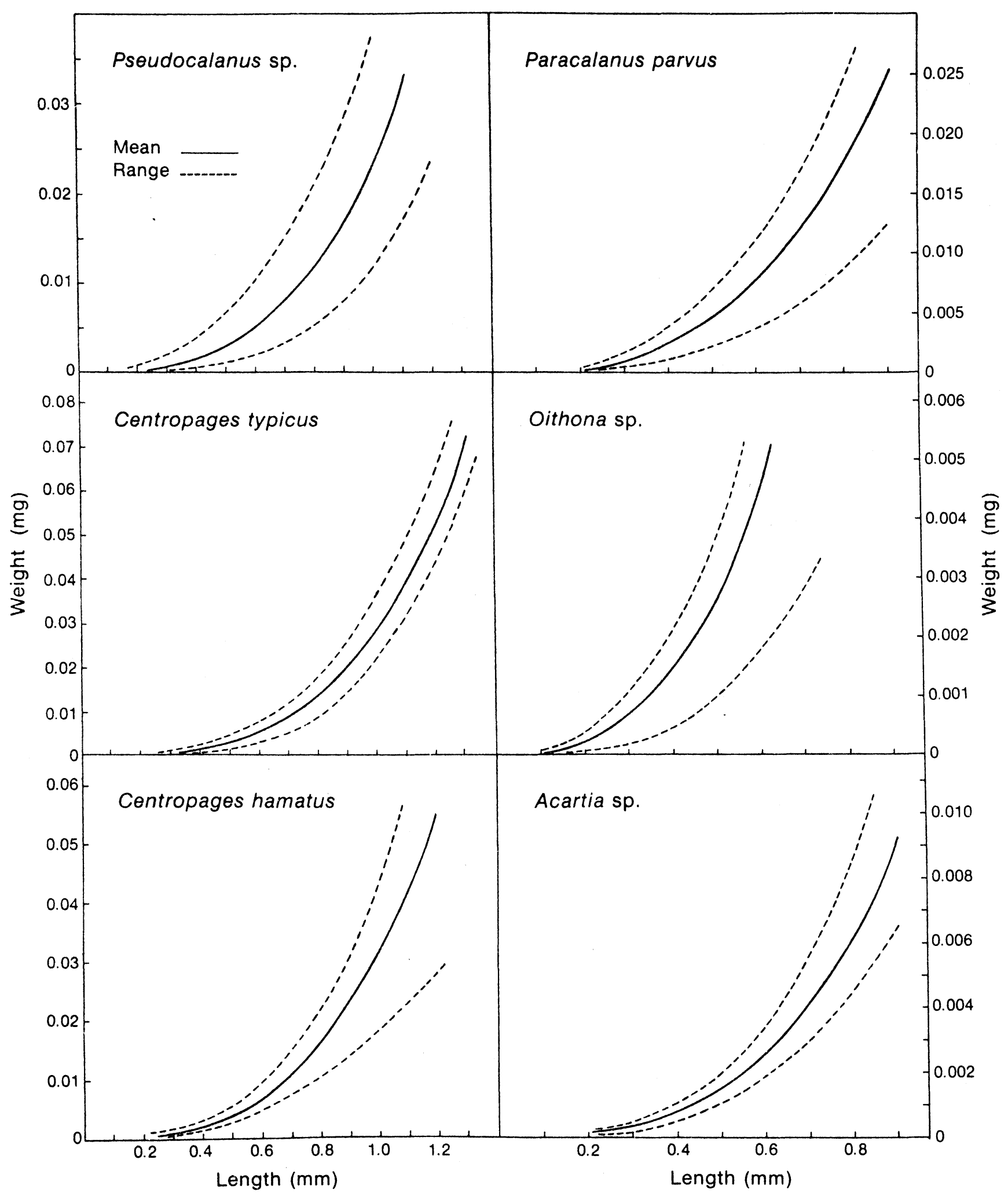

Fig. 1. Composite length-weight relationships for Pseudocalanus sp., Paracalanus parvus, Centropages typicus, Centropages hamatus, Oithona sp., and Acartia sp., showing the mean curves and the ranges of observations. 


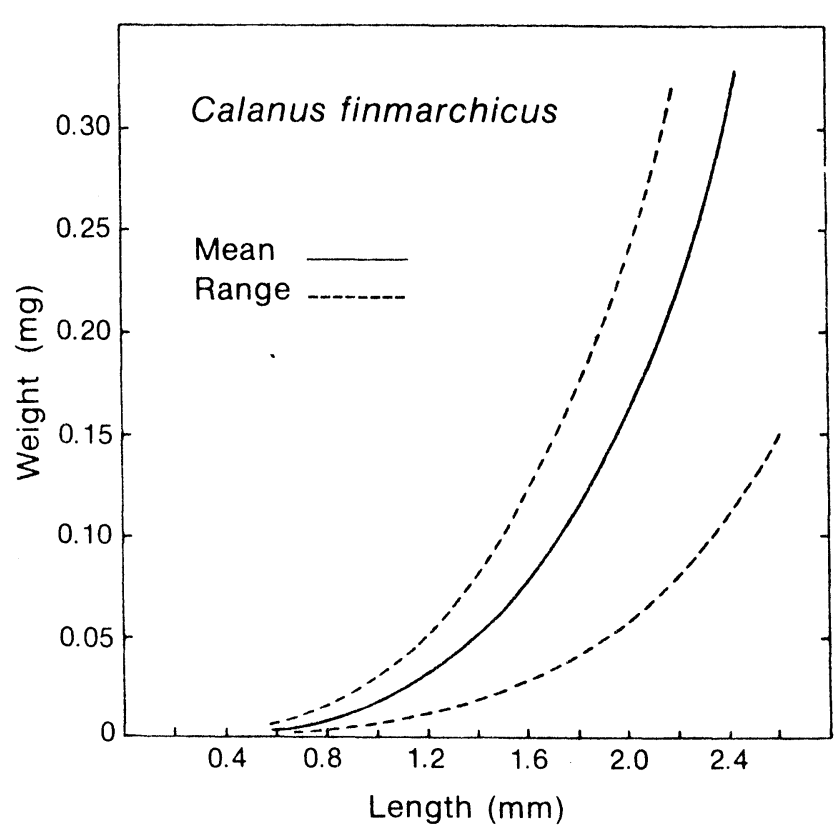

Fig. 2. Composite length-weight relationship for Calanus finmarchicus, showing the mean curve and the range of observations.

only be used in studies involving a limited taxonomic group of organisms, and he also encouraged the development of in situ methods of biomass measurement for routine surveys.

\section{References}

ANON. MS 1976. Equation for wet weight calculation (W) in most important zooplankton groups by size L. Unpublished USSR data report. U.S. Nat. Mar. Fish. Serv., Northeast Fisheries Center, Woods Hole Laboratory, $16 \mathrm{p}$.

BEERS, J. R. 1976. Determination of zooplankton biomass. In: Monographs on oceanographic methodology. IV. Zooplankton fixation and preservation. H. F. Steedman (ed.). UNESCO Press, Paris, France, p. 35-84.

BOGOROV, B. G. 1934. Seasonal change in biomass of Calanus finmarchicus in the Plymouth area in 1930. J. Mar. Biol. Assoc. U. K., 19: 585-611.

CHISLENKO, L. L. 1968. Nomographs for determination of weight of water organisms according to size and form of body (marine meiobenthos and plankton). Science, Leningrad division, $104 \mathrm{p}$.

COHEN, R. E., and R. G. LOUGH. MS 1979. Laboratory and data processing methods recommended for larval fish gut content and condition factor analysis studies using larval sea herring (Clupea harengus L.) as a prototype. U.S. Nat. Mar. Fish. Serv., Northeast Fisheries Center, Woods Hole, Lab. Ref. No. 79-39, 64 p.

COHEN, R. E., R. G. LOUGH, and J. A. MURPHY. MS 1980. Larval herring (Clupea harengus $L$.) gut content and morphological condition data from three spawning seasons $(1974,1975$, and 1976) in the Georges Bank-Gulf of Maine area. U.S. Nat. Mar. Fish. Serv., Northeast Fisheries Center, Woods Hole, Lab. Ref. No. 80-23. $143 \mathrm{p}$.

COMITA, G. W. 1966. On the biology of Calanus finmarchicus. XIII. Seasonal changes in weight, calorific value and organic matter. $J$. Mar. Biol. Assoc. U. K., 46: 1-17.

CONOVER, R. J. 1968. Zooplankton-life in a nutritionally dilute environment, Am. Zool., 8: 107-118.

CORKETT, C. J., and I. A. MCLAREN. 1978. The biology of Pseudo- calanus. In: Advances in Marine Biology. F. S. Russell and M. Yonge (ed.). Academic Press, New York, 15: 1-231.

DAVIS, C. S. MS 1977. Length-weight relationships in the copepod Pseudocalanus minutus on Georges Bank. U.S. Nat. Mar. Fish. Serv., Northeast Fisheries Center, Woods Hole Laboratory, Unpubl. data report, $20 \mathrm{p}$.

DEEVEY, G. B. 1960. Relative effects of temperature and food on seasonal variations in length of marine copepods in some eastern American and western European waters. Bull. Bingham Oceanogr. Coll., 17: 54-86.

DURBIN, E. G., and A. G. DURBIN. 1978. Length and weight relationships of Acartia clausi from Narragansett Bay. Limnol. and Oceanogr., 23: 958-969.

FUDGE, H. 1968. Biochemical analysis of preserved zooplankton. Nature, 219: 380-381.

GRUZOV, L. N., and L. G. ALEKSEYEVA. 1970. Weight characteristics of copepods from the equatorial Atlantic. USSR Acad. Sci., Oceanology, 10: 871-879.

HERMAN, A. W., and T. M. DAUPHINEE. 1980. Continuous and rapid profiling of zooplankton with an electronic counter mounted on a 'Batfish' vehicle. Deep-Sea Res., 27: 79-96.

IVLEV, V. S. 1961. Experimental ecology of the feeding of fishes. Yale Univ. Press, New Haven, $301 \mathrm{p}$.

KAMSHILOV, M. M. 1951. Determination of weight of Calanus finmarchicus (Gunnerus) on the basis of measuring length of body. Rep. Acad. Sci. USSR, 76: 945-948.

KRYLOV, V. V. 1968. Relation between wet formalin weight of coepods and copepod body length. USSR Acad. Sci. Oceanology, 8: 723-727.

LANDRY, M. R. 1978. Population dynamics of a planktonic marine copepod, Acartia clausi, in a small temperate lagoon on San Juan Island, Washington. Int. Rev. Hydrobiol., 63: 77-119.

LASKER, R. 1973. Utilization of zooplankton energy by a Pacific sardine population in the California Current. In: Marine food chains, J. H. Steele (ed.). Oliver and Boyd, Edinburgh, p. 265-284.

LAURENCE, G. C. 1977. A bioenergetics model for the analysis of feeding and survival potential of winter flounder, Pseudopleuronectes americanus, larvae during the period from hatching to metamorphosis. Fish. Bull. U.S., 75: 529-546.

LOVEGROVE, T. 1966. The determination of the dry weight of plankton and the effect of various factors on the values obtained. In: Some contemporary studies in marine science, $\mathrm{H}$. Barnes (ed.). George Allen and Unwin Ltd., London, p. 429-467.

MCLAREN, I. A. 1963. Effects of temperature on growth of zooplankton and the adaptive value of vertical migration. J. Fish. Res. Bd. Canada, 20: 685-727.

MULLIN, M. M., and E. R. BROOKS. 1970. The effect of concentration of food on body size, cumulative ingestion, and rate of growth of the marine copepod Calanus helgolandicus. Limnol. and Oceanogr., 15: 748-755.

PEARRE, S., Jr. 1980. The copepod width-weight relation and its utility in food chain research. Can. J. Zool., 58: 1884-1891.

PERTSOVA, N. M. 1967. Mean weights and measurements for massive species in the zooplankton of the White Sea. Okeanologiya, 7: 309313.

RADTKE, R. L., and J. M. DEAN. 1979. Feeding, conversion efficiencies, and growth of larval mummichogs, Fundulus heteroclitus. Mar. Biol., 55: 231-237.

ROBERTSON, A. 1968. The continuous plankton recorder: a method for studying the biomass of calanoid copepods. Bull. Mar. Ecol., 6: 185-223.

SCHWARTZ, J. P. 1977. A method for estimating biomass for allometric growth of Calanus finmarchicus (Gunnerus) from Georges Bank. U.S. Nat. Mar. Fish. Serv., Northeast Fisheries Center, Narragansett, Lab. Ref. No. 77-18, 30 p.

SHERMAN, K. 1980. MARMAP, a fisheries ecosystem in the NW Atlantic: fluctuations in ichthyoplankton-zooplankton components and their potential for impact on the system. In: Advanced concepts in ocean measurements for marine biology, F. P. Diemer, F. J. Vernberg, and D. Z. Mirkes (eds.). Univ. South Carolina Press, Columbia, p. 9-37. 
SHERMAN, K., D. BEARSE, and L. SULLIVAN. 1979. Variations in the zooplankton biomass of Georges Bank in the spring of 1976 and 1977. ICES Ann. Biol., 34: 87-90.

SHMELEVA, A. A. 1963. Weight characteristics of the most widespread forms of Adriatic Sea zooplankton. Tr. Sevast. Biol., 15.
SIEFKIN, M., and K. B. ARMITAGE. 1968. Seasonal variation in metabolism and organic nutrients in three Diaptomus (Crustacea: SIEFKIN, M., and K. B. ARMITAGE. 1968. Seasonal variation in metabolism and organic nutrients in three Diaptomus (Crustacea: Copepoda). Comp. Biochem. Physiol., 24: 591-609. 